\title{
3 次元乱流モデルによる密度流の進入と 内部セイシュに関する数値計算 3-D NUMERICAL CALCULATION OF DESITY FLOW FOR ADVANCE AND INNER SEICHE
}

\author{
${\text { 赤堀良介 }{ }^{1} \cdot \text { 清水康行 }^{2} \text {. 中山卓 }}^{3}$ \\ Ryosuke AKAHORI, Yasuyuki SHIMIZU and Suguru NAKAYAMA \\ 1 学生員北海道大学大学院工学研究科 ( $\bar{T} 060$ 札幌市北区北 13 条西 8 丁目) \\ 2 正会員 工博 北海道大学大学院工学研究科助教授 ( $\bar{T} 060$ 札幌市北区北 13 条西 8 丁目) \\ 3 学生員北海道大学大学院工学研究科 ( $\bar{T} 060$ 札幌市北区北 13 条西 8 丁目)
}

\begin{abstract}
In the stratified closed water systems such as bays, lakes, and river mouths flowing into sea, the unique phenomena caused by the density differences are observed. Numerical simulation is useful for investigating such phenomena and three-dimentional numerical models are required when it have occured under the effects of changeable wind direction and complicated ground shape. In this paper, a three-dimensional numerical model which employs LES and CIP methods is proposed for the purpose of calculating incompressible density current. The model is closs-checked by the results of an experimental density flow in a flume, in which the movement of density front and internal seiche can be observed. The applicability of such a process is confirmed by the calculated results of miglation of density front, vortexes behind it, diffusion of inner density boundary, and period of internal seiche.
\end{abstract}

Key words: $3 D$ numerical calculation, density flow, CIP, LES.

\section{1. はじめに}

水温や塩分濃度の違いにより成層化した閉鎖性水域 内では, 気温の急激な変化による逆転層や, 吹送流によ り引き起こされる青潮などといった特異な現象が観察 される場合がある。またそれら成層化水域への洪水時 の流入水や, 河川河口部の海域との境界部における潮の 干満やゲート操作に伴う塩水の遡上, 流入によって, 密 度フロントが形成される事例も北海道東部の網走川河 口に位置する網走湖などで報告されている ${ }^{1)}$.

これら流体の密度差に起因した現象は, その周辺環境 に与える影響も大さい場合が多く，問題の対策や予測に 当たつて異なった密度の流体が混在する水域特有の水 理機構を理解していくことが非常に重要となる。これ は水域内における水質問題が, 污染水域の形成やその水 表面への発露, 水域外一の排出に際して, 水循環の水理 的なシステムと不可分な関係にある為である.

このような成層化水域や河川河口部で観察される密 度流現象の理解の方法の一つとして, 計算機による数值 計算がある. 数值計算においては, 現象の発生している 空間内の詳細な逐次的データが得られることから, 実験 や観測では得られない部分を補完する膨大な情報をも たらすことが期待される。これまでにも成層化水域に おける水理学的問題への数值計算を用いた研究として, 道奥ら ${ }^{2)}$ による $k-\epsilon$ モデルでの半閉鎖水域の水理特 性の研究, 池永ら ${ }^{3)}$ による多層のレベルモデルでの網 走湖の密度界面の挙動の再現, 細田ら ${ }^{4)}$ による交換密 度流の密度フロントの鉛直 2 次元流れの数值解析等が

\section{発表されている.}

筆者らも過去に CIP 法 ${ }^{5)}$ を用いた 2 次元非圧縮流体 の密度流数值計算モデル 6$)$ の構築を行い, 実験との比 較においてモデルの妥当性を確認してきた。しかしな がら実際の水域で現象が発生する場合は, 地形による影 響や上空の吹送方向の変化のためにその現象は 3 次元 性を持った複雑なものとなり, 鉛直 2 次元断面の数值計 算からだけでは考察できない部分が多く, 3 次元数值計 算モデルの構築が必要とされる.

そこで本研究では, 非圧縮性流体における 3 次元密度 流数值計算モデルを提案し，それにより行った計算と， 同様の条件のもとで行われた実験との比較をすること によりモデルの妥当性を検証することとした. 3 次元に おいて乱流を数值的に計算していく場合, 乱流モデルを 用いて計算格子より小さいスケールの渦をモデル化す るか, もしくは計算格子を Kolmogoroff スケール以下 として直接数值計算を行う必要があるが, 今回は乱流モ デルとして, 非定常の流れを計算する場合に効果をもつ $\mathrm{LES}^{7)}$ を用いた。 また基礎式の運動方程式中の移流項 の計算には CIP 法を用いることとした. CIP 法は, 移 流項における格子間の物理量のプロファイルを 3 次式 を用いて補完する方法であり，一般的な風上差分と比較 して物理量の分布を精度よく捉えることが可能である ため, 本論のような密度流の数值計算においては結果の 高精度化に有効であると思われる。

またさらに，そのモデルを用いた数值計算による結果 を可視化し, グラフィカルに検討していくことで, 今回 の計算対象における密度流現象の 3 次元性について考 


\section{2. 基礎式と計算方法}

LES による三次元非圧縮流体の密度流の計算にあたっ て，以下のスマゴリンスキーモデルを用いた連続の式 (1) と運動方程式 (2), 密度の移流・拡散の方程式 $(3)^{8)}$ を基 礎式とする。

$$
\begin{gathered}
\frac{\partial \bar{u}_{i}}{\partial x_{i}}=0 \\
\frac{\partial \overline{u_{i}}}{\partial t}=-\frac{1}{\rho} \frac{\partial P}{\partial x_{i}}+H_{i} \\
\frac{\partial \bar{\rho}}{\partial t}+\frac{\bar{u}_{j} \partial \bar{\rho}}{\partial x_{j}}=-\frac{\partial h_{j}}{\partial x_{j}}+\frac{\partial}{\partial x_{j}}\left(\alpha \frac{\partial \bar{\rho}}{\partial x_{j}}\right)
\end{gathered}
$$

また運動方程式 (2) 内の各文字は, 次のように与えら れる。

$$
\begin{gathered}
P=\bar{p}+\frac{2}{3} q, \quad H_{i}=-\frac{\partial \overline{u_{i}} \overline{u_{j}}}{\partial x_{j}}+\frac{\partial}{\partial x_{j}}\left(2 \nu_{e} \overline{S_{i j}}\right)+g_{i} \\
\nu_{e}=\nu+\nu_{t}, \quad \nu_{t}=\left(C_{s} \Delta\right)^{2}\left(2 \overline{S_{i j}} \overline{S_{i j}}\right)^{1 / 2} \\
\overline{S_{i j}}=\frac{1}{2}\left(\frac{\partial \overline{u_{i}}}{\partial x_{j}}+\frac{\partial \overline{u_{j}}}{\partial x_{i}}\right) \\
h_{j}=-\alpha_{t} \frac{\partial \bar{\rho}}{\partial x_{j}}, \quad \alpha_{t}=\frac{\nu_{t}}{P r_{t}}
\end{gathered}
$$

ただし, 計算格子は図- 1 左上部に示される $x, y, z$ 軸で 定義される直交座標上にとるものとし $t$ は時間, $\bar{u}_{i}$ は流 速, $x_{i}$ は座標軸, $g_{i}$ は各軸方向の重力加速度, $\nu$ は動粘性 係数, $\alpha$ は拡散係数, $\bar{p}$ は圧力の平均量, $q=\nu_{t}{ }^{2} /\left(C_{k} \Delta\right)^{2}$, $C_{k}=0.094, \bar{\rho}$ は密度の平均量, $C_{s}$ はモデル定数, $P r_{t}$ はプラントル数, $\Delta=(\Delta x \Delta y \Delta z)^{1 / 3}$ である.

本論で提案されるモデルの特色の一つに CIP 法 があ げられる. その基本的な特色は, 基礎式中の移流項計算 において計算格子間の物理量の分布を 3 次方程式で補 完する点, さらにその物理量の 1 階微分値も同様に移流 していると考えることで計算に必要とされる格子点の 数を少数に留め, かつ高精度な解を得る点にある. 本論 における計算に当たっては CIP 法 を導入するために, 運動方程式 (2) と密度の移流・拡散の方程式 (3) の計算 に分離解法を用いている。 またブジネスク近似 ${ }^{9)}$ を導 入することで, 密度の空間的な変化は浮力項にのみ作用 すると考える事が出来るため, 圧力項の解法を簡単な形 とすることが可能となる。

ここで CIP 法の概要について, 簡単のため一次元の 波動方程式 (8) を例にとって説明する.

$$
\frac{\partial C}{\partial t}+V \frac{\partial C}{\partial x}=0
$$

これはある物理量 $C$ が，そのままの分布形状を保ち ながら流速 $V$ によって $x$ 軸上を運ばれていくことを示 している

このとき数值計算においては各格子点上の值しか知 ることができないため, 次の時刻のある点での $C$ の值
を得るためには，現在の時刻における格子間の $C$ のプ ロフィールを推定する必要がある。

ここでは式 (9)によって表わされる三次曲線によって, それぞれの格子間のプロフィールを仮定する.

$$
F_{i}(x)=a_{i}\left(x-x_{i}\right)^{3}+b_{i}\left(x-x_{i}\right)^{2}+C_{i}{ }^{\prime}\left(x-x_{i}\right)+C_{i}
$$

ここで未知数は $a_{i}, b_{i}, C_{i}{ }^{\prime}$ の 3 つである. CIP 法で は，まず各格子点で值が連続であるという条件と，その 一階微分が連続という 2 つの条件式 (10),(11) から式 (12),(13) を得る。

$$
\begin{gathered}
F_{i}\left(x_{i-1}\right)=F_{i-1}\left(x_{i-1}\right) \\
d F_{i}\left(x_{i-1}\right) / d x=d F_{i-1}\left(x_{i-1}\right) / d x \\
a_{i}=\frac{C_{i}{ }^{\prime}+C_{i+1}{ }^{\prime}}{\delta x^{2}}-2 \frac{C_{i+1}-C_{i}}{\delta x^{3}} \\
b_{i}=3 \frac{C_{i-1}-C_{i}}{\delta x^{2}}+\frac{2 C_{i}{ }^{\prime}+C_{i-1}{ }^{\prime}}{\delta x}
\end{gathered}
$$

以上から $a_{i}, b_{i}$ が $C, C^{\prime}$ によって決定されることがわ かる. しかしこの 2 つの式だけでは 3 つの未知数を求 めることができないため,もう一つ条件を与える必要が ある。

そこで CIP 法では $C_{i}$ の一階の空間微分の $C_{i}{ }^{\prime}$ も同 様に移流していると仮定することにより，(8) 式におい て $C$ が $C(x, t)=C(x-V \delta t, t-\delta t)$ を満たすように, (14) 式において $C^{\prime}$ が $C^{\prime}(x, t)=C^{\prime}(x-V \delta t, t-\delta t)$ を 満たすと考える.

$$
\frac{\partial C^{\prime}}{\partial t}+V \frac{\partial C^{\prime}}{\partial x}=0
$$

ここで $C, C^{\prime}$ を既知数として与えると式 $(12),(13)$ よ り $a_{i}, b_{i}$ が得られる.この $a_{i}, b_{i}$ を用いて式 $(15)(16)$ か ら次の時刻の $C^{\text {new }}, C^{\prime n e w}$ を求めていくこととする.

$$
\begin{aligned}
& C_{i}{ }^{n t w w}=F_{i}^{\prime}\left(x_{i}-V \delta t\right)=\left[\left(a_{i} \xi+b_{i}\right) \xi+C_{i}{ }^{\prime}\right] \xi+C_{i} \\
& C_{i}{ }^{\text {new }}=\frac{F_{i}\left(x_{i}-V \delta t\right)}{d x}=\left(3 a_{i} \xi+2 b_{i}\right) \xi+C_{i}^{\prime}
\end{aligned}
$$

ただし $\xi=(-V \delta t)$ である.

実際の計算にあたってはこれらの考え方を 3 次元化 し, 基礎式中の移流項について分離解法を用いて適用 した.

次に分離解法の手順について述べる.下記の流れ図の 中で, $u_{i}$ は各流速, $\rho$ は密度, 肩文字 $n, n+1$ は時間ス テップ, $\widehat{u_{i}}, \widetilde{u_{i}}, \widetilde{\rho}$ は, 各ステップでの流速, 密度の中間 值を示している.まず式 (2), (3) を差分化し, 移流項と それ以外の項に分離する. 運動方程式 (2) についてはさ らに二段階分離解法によって, 同一の時間ステップでの 流速を, 压力項と粘性項とに分離して段階的に求める. この段階が下記の (a), (b) であり, この際圧力項の圧力 $P$ の值は, 連続式 (1) を満足させるように SOR 法を用 いてポアソン方程式を計算することによって求められ る.この後, 移流項の解を CIP 法によって求め, 次の時 間ステップの流速と密度が得られる。これが (c) の段階 


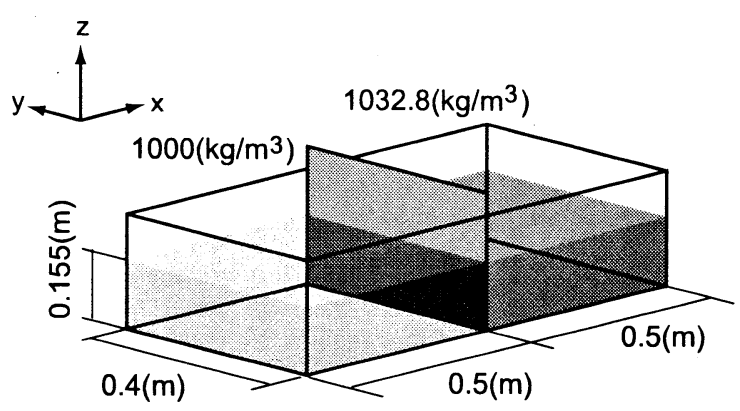

図-1 初期条件

である。これらの手順を繰り返す事により, 逐次的に流 速, 密度を求めていく。

(a)

(b)

(c)

$$
\begin{aligned}
& u_{i}^{n} \longrightarrow \widehat{u_{i}} \longrightarrow \tilde{u}_{i} \longrightarrow u_{i}^{n+1} \\
& \rho^{n} \quad \longrightarrow \quad \tilde{\rho} \longrightarrow \rho^{n+1}
\end{aligned}
$$

(a) 非移流項 (圧力項)

(b) 非移流項 (粘性項・拡散項)

(c) 移流項 $\longrightarrow$ CIP Method

なお境界条件であるが，底面と壁面において，対数則 が成り立つとして流速を与えた。また水面は自由水面 であるが, 今回は水位の変化が十分に小さいと考えられ るため,一定であると近似している.

\section{3. 初期条件}

計算と実験を行うにあたっての初期条件を図-1に示す。

長さ $1.0(\mathrm{~m})$, 幅 $0.4(\mathrm{~m})$ の水槽を仕切り板によって分 割し, 水深 $0.155(\mathrm{~m})$ で左側には密度 $1000\left(\mathrm{~kg} / \mathrm{m}^{3}\right)$ の液 体, 右側には密度 $1032.8\left(\mathrm{~kg} / \mathrm{m}^{3}\right)$ の液体を満たす. 時刻 $0.0(\mathrm{sec})$ と同時にこの仕切り板は取り外され, 液体は自 由に移動できるようになる。

また実際の実験では, 長さ $1.0(\mathrm{~m})$, 高さ $0.3(\mathrm{~m})$, 奥行き $0.4(\mathrm{~m})$ の透明なアクリル水槽を中央で仕切り板によって 分割し, 水深 $0.155(\mathrm{~m})$ で, 左側には密度 $1000.0\left(\mathrm{~kg} / \mathrm{m}^{3}\right)$ の淡水, 右側にはメチレンブルーによって着色された密 度 $1032.8\left(\mathrm{~kg} / \mathrm{m}^{3}\right)$ の塩水を満たすことで計算と同様の 初期条件を得ている. 実験開始と同時にこの仕切り板 は取り外され，この様子をデジタルビデオカメラで撮影 する. 撮影した映像はコンピューターに取り込み静止 画像化し, 数值計算による計算結果との比較, 検証に用 いている.

また各変数はそれぞれ $, \nu=0.000001\left(\mathrm{~m}^{2} / \mathrm{sec}\right), \alpha=$ $0.000002\left(\mathrm{~m}^{2} / \mathrm{sec}\right), C_{s}=0.1, P r_{t}=0.5$ とし, 計算メッ シュは $x, y, z$ 軸方向にそれぞれ $100,40,15$ とした.

\section{4. 計算結果と実験との比較・画像か らの考察}

本モデルによる前述の条件による計算結果を, 以下に 可視化して示し, 実験との比較を行う.

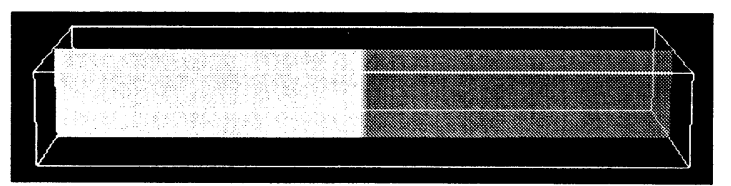

$\mathrm{t}=0.0(\mathrm{sec})$

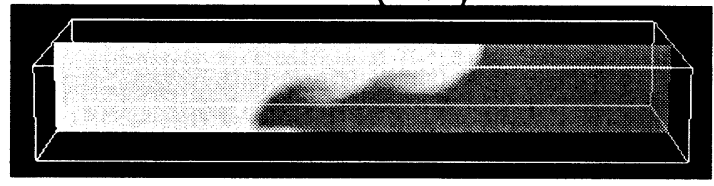

$\mathrm{t}=2.1(\mathrm{sec})$

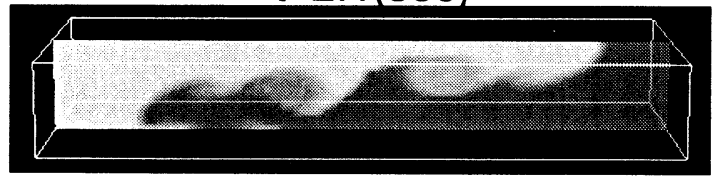

$\mathrm{t}=4.1(\mathrm{sec})$

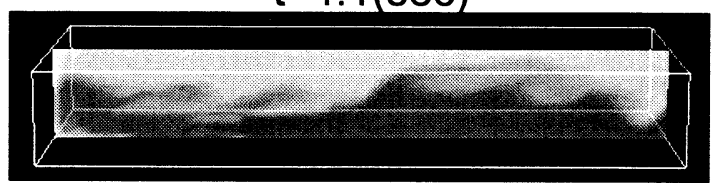

$\mathrm{t}=6.1(\mathrm{sec})$

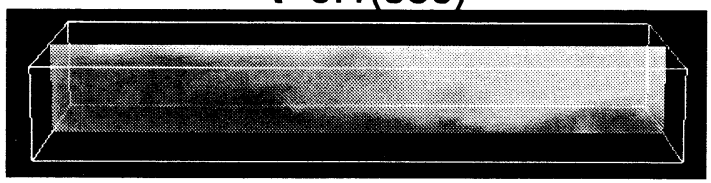

$\mathrm{t}=12.2(\mathrm{sec})$

図-2計算結果における水路中央の密度分布を グレースケールの濃淡により示した画像

図-2 は計算結果における水路中央部の密度分布を, グ レースケールの濃淡により示したものであり，色の濃い 部分が密度の高い部分を表している.また図-3 は, 実験 を水路側面横断方向からデジタルビデオにより撮影し， コンピューターに取り込み静止画像化したものである. 実験において塩水はメチレンブルーにより青く着色さ れているため, 図-3に㧧密度の高い部分ほど色が濃 く表されていると考えられる。

本論では, 筆者らの 2 次元非圧縮流体密度流数値計算 モデル5）を用いた研究と同様, 図-2, 図-3において画像 の濃淡によって示される密度フロントの形状や形成の 過程, 内部界面の挙動を比較することで, モデルの妥当 性を検討することとする. 本来は内部の流速や密度分 布を正確に計測した上で比較することが理想的ではあ るが, 流速や密度分布の詳細な計測は困難であり, 可視 化された計算結果と実験結果をもとに定性的な比較を 行った.

両者の図を比較すると, 密度フロントの進入過程と内 部セイシュが計算において良好に再現されていること がわかる. 特に計算開始直後の, フロント後方と中央部

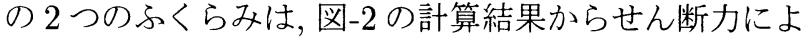
る渦だと推測されるが, 形状や進入の速度などほぼ一致 しているといえる．その後境界面が流下方向に長く伸 びていくのに伴い, 当初のフロント後方と中央の 2 つ 大きな渦は中央に残され, 新たなフロントとその後方の 渦が形作られていく. 計算結果では実験結果と比較し て, 密度分布がより鮮明に捉えられているが, 全体的な 密度分布の形状は良く再現されているといえる。また セイシュの周期も実験と計算でほぼ同様の結果が得ら 


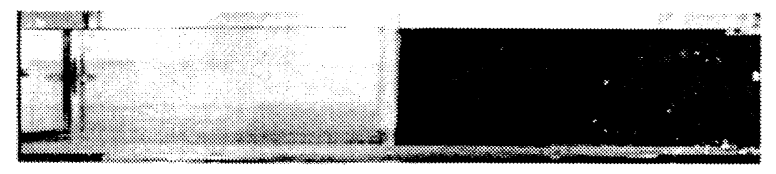

$\mathrm{t}=0.0(\mathrm{sec})$

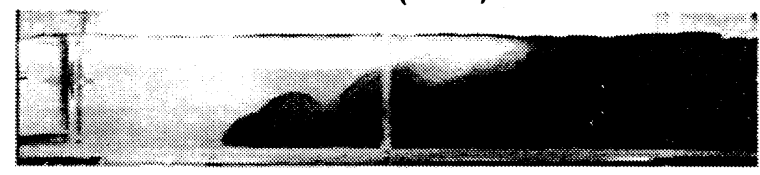

$\mathrm{t}=2.1(\mathrm{sec})$

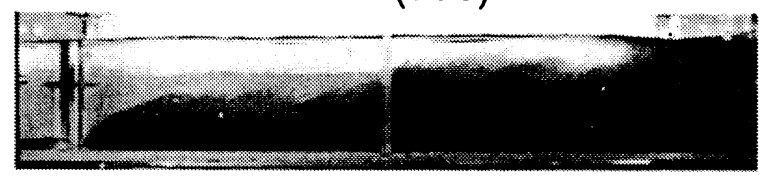

$\mathrm{t}=4.1(\mathrm{sec})$

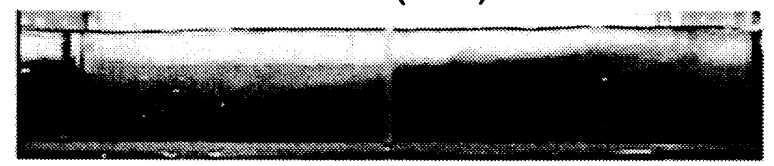

$\mathrm{t}=6.1(\mathrm{sec})$

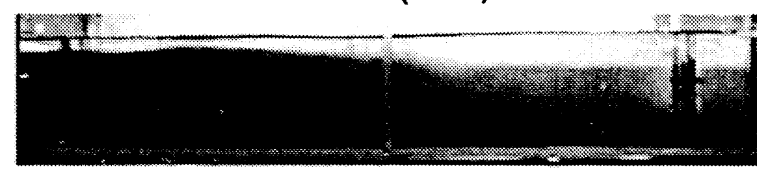

$\mathrm{t}=12.2(\mathrm{sec})$

図-3＼cjkstart実験における水路側面横断方向から デジタルビデオにより撮影された画像 (着色された部分が塩水を示す)

れていることが分かる

次に過去に行われた類似の実験と計算の結果とを比 較する事で，今回提案されたモデルの有効性を検証す る. 今回のモデルを用いて, 最初の計算から $2.0(\mathrm{~cm})$ づ つ水位を下げた初期条件での計算を 4 種類行い, フロン 卜部における混合層厚, 下層厚, Reynolds 数を, 検討の ためのデータとした，その他の初期条件はすべて同様 である。

比較の対象には, 筆者らの 2 次元モデルでも対象とし た, 第 1 章で述べた細田らの交換密度流の密度フロン トの計算結果と, 同研究で引用されている Simpson ら 10)，および大久保 11) の実験結果を用いる事とする。こ れは過去の密度流数值計算モデルにおいて問題とされ てきた密度界面の保存性について本モデルが有効であ るかを, 混合層の厚み(数值粘性による誤差が大きい場 合，実験値と比較して過大に評価されると考えられる) によって確認するためである。実験条件や初期条件が 今回行った計算とは異なるため厳密な比較を行う事は できないが，フロントの形状特性のおよその傾向は確認 できると考えられる.

図-4 は混合層厚と Reynolds 数の関係を示したもので ある.ただし $H$ は水深, $h 3$ は混合層厚, $h 4$ は下層厚で あり, $R e=u_{2} R / \nu$, Okubo の実験においては $R$ は下層 流の径深, 計算では $H / 4$ として評価する.また $u_{2}$ はフ ロントの伝播速度である。

この図から，今回の計算結果は実験値と同様の分布を 示しており，良好な結果を表しているといえる.

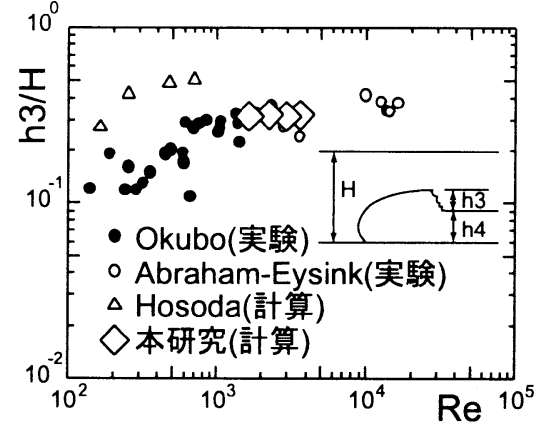

図-4 混合層厚と Reynolds 数の関係

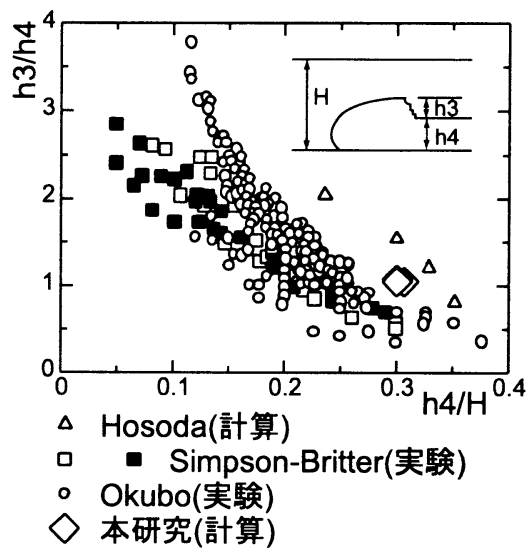

図-5 混合層厚と下層厚の関係

図-5 は混合層厚と下層厚の関係を示したものである。 この図においても今回の計算値は実験值と比較的近い ところに分布しているといえる.

また，フロントの移動速度に関して，大久保らの実験 においても比較対象として用いられている Barr らの実 験 ${ }^{11)}$ と簡単に比較を行った。このとき $T / T_{\Delta}$ の值に 10 と 20 をとるため, 水路の長さと幅のみを，これまでの計 算とは変更している. $T / T_{\Delta}=10$ のとき, $\mathrm{Re}=2906.25$ に対する $\mathrm{L} / \mathrm{H}$ は，実験から得られた值約 4.5 に対して， 本モデルによる計算值が 3.38 であり, $T / T_{\Delta}=20$ のと きは, $\mathrm{Re}=2906.25$ に対する $\mathrm{L} / \mathrm{H}$ は, 実験から得られた 值約 9.0 に対して, 本モデルによる計算值が 6.93 となる. 計算值はやや $\mathrm{L} / \mathrm{H}$ が小さいが，オーダー的には比較的近 い值となった.ただし，Lは初期隔壁位置から測ったフ ロント長, $T$ はこの延びに要する時間, $T_{\Delta}=\left(H / g^{\prime}\right)^{1 / 2}$, $\mathrm{H}$ は水深, $g^{\prime}=(\Delta \rho / \rho) g, \Delta \rho$ は密度差, $g$ は重力加速度 である。

以上より，同条件で行われた実験と計算結果との目視 による比較と, 過去の類似実験とのグラフによる比較か ら, 本モデルの密度流計算における妥当性が確認できた。

図-6 は水路内，左右の液体密度の中間値である密度 $1016.4\left(\mathrm{~kg} / \mathrm{m}^{3}\right)$ の等值面の, 計算結果から得られた時間 的な変化を示したものである。前述のように右側には 塩水, 左側には淡水が満たされている状況を想定してい る。また図中の白い点は水路中央の鉛直断面に置かれ たトレーサーである。

時刻 $\mathrm{t}=0.0(\mathrm{sec})$ に左右の液体間の拘束が外れると同 時に, 右側に満たされていた密度の高い液体が左側に潜 りこんでいくことによって密度フロントが形成されて 行く様子が確認できる。その後のフロントの進行過程 を詳細に観察すると, 時刻 $\mathrm{t}=2.0(\mathrm{sec})$ の画像からフロ 

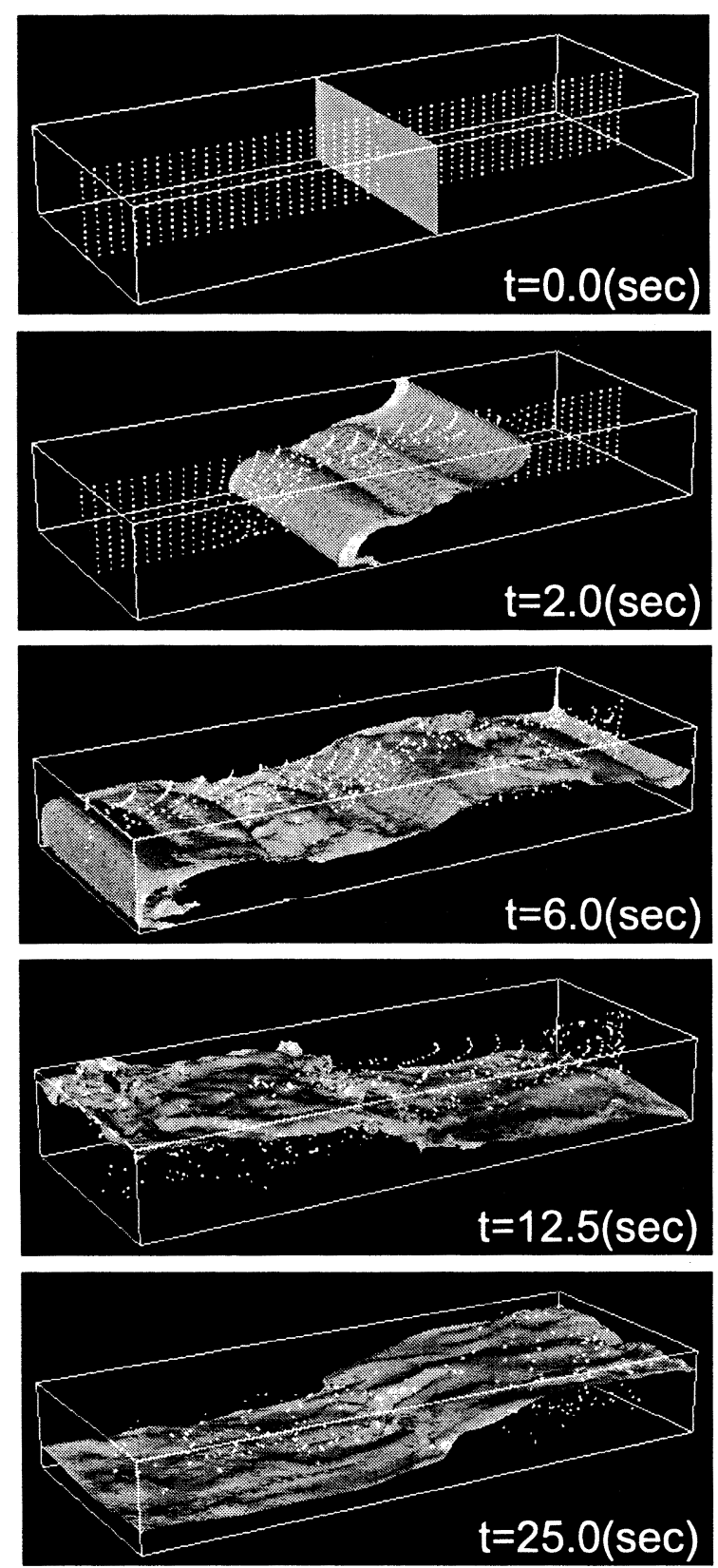

図-6 計算結果: 密度 $1016.4\left(\mathrm{~kg} / \mathrm{m}^{3}\right)$ の等値面

ントの発達に伴い, 等值面上のフロント後方と水路中央 部に二つの大きな膨らみの発生が見られる。これは前 述のように密度境界面に働くせん断力により発生した 渦によるものと考えられ, 図-3 で示す実験から得られた 画像からも確認できる。

密度フロントは時刻 $\mathrm{t}=6.0(\mathrm{sec})$ 程度で水路の左端に 達し, 時刻 $\mathrm{t}=12.5(\mathrm{sec})$ 前後で密度境界面の水位が水路 左側で最も上昇する.この後水路内は緩やかに成層化し, フロントの形態は消滅して境界面の内部セイシュが開 始される。この内部セイシュの周期は, 計算開始からの 一巡目が $25(\mathrm{sec})$ 程度であり，上下層の厚さをそれぞれ $0.155 / 2(\mathrm{~m})$ とした場合の理論值である約 $18.2(\mathrm{sec})^{12)}$ とは若干異なるものの, 実験により観測された周期とほ ぼ一致する. またフロントの左端到達以降の画像から， 水路横断方向に向かう高周波が等值面に発生している 様子が見られ，内部境界面の動きが，フロントの左端へ の衝突と前後して 3 次元性を帯びるということが確認

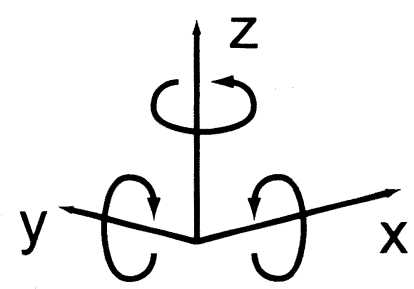

図-7 各軸方向の渦度の模式図

できる.

図-8, 図-9, 図-10 は, それぞれ図-7によって示される $x, y, z$ 軸方向周りの渦度の等值面と水路中央の鉛直断 面上の密度分布を同時に示したものである. $x$ 軸は水路 縦断方向, $y$ 軸は水路横断方向, $z$ は垂直方向にとられ ており, 密度フロントの進行に伴う密度界面のせん断力 が $y$ 軸周りに働くことから, 流れの 2 次元性が強い場合 は, 図-9に示された $y$ 軸周りの渦度が卓越する. 逆に 3 次元性が強い場合は図-8, 図-10 に示された $x$ 軸, $z$ 軸周 りの渦度が発達すると考えることが出来る.

図-8に示された $x$ 軸周りの渦度は, 当初水路の壁 近傍において発達を見せ万。この亡きの样子が図中 $\mathrm{t}=2.0(\mathrm{sec})$ に示されている. 密度フロントの進入過程 の初期の段階では水路全体に鉛直断面に沿った 2 次元 的な流れが卓越しているため, 壁とのせん断力によって しか $x$ 軸方向周りの渦度が発生していない.しかしな がら $\mathrm{t}=3.5(\mathrm{sec})$ の画像を見ると, 同 $x$ 軸周りの渦度の 発達が, 徐々に水路内部に向かい 3 次元的に発達してい く様子が確認できる。この渦度の等值面が, 密度分布で 示された水路中央部の渦に向かっていることから，まず $y$ 軸周りに発達した渦による巻き込みが, 次第に $x$ 軸周 りの渦度を発生させていったのではないかと考えられ る. その後の $\mathrm{t}=9.0(\mathrm{sec})$ の画像から; 水路内の流れはフ ロントの左端到達に前後して. 急速に 3 次元性を帯び ていくことが観察される。これはフロントが左端の壁 にぶつかり消滅することで，これまで流下方向に卓越し ていた流れのエネルギーが水路の両端よりの空間全体 に拡散していくためであると考えられる。

図-9 を見ると，ほぼ常に $y$ 軸周りの渦度がその他の軸 まわりの渦度に比較して卓越していることが分かる. フ ロントの進入に伴い密度境界面に働くせん断力が強く $y$ 軸周りの渦度を発生させているためである. ただしフ ロントの左端到達時に他軸周りの渦度が水路内全体に 拡散していくのに伴い, $y$ 軸周りの渦度はいったん急速 に減少する. 境界面水位が水路左側で最も高くなる直 前には, 最小となるが, 塩水が右側に戻っていくときに はまた大きな発達が見らる。

図-10 は $z$ 軸周りの渦度を示しており, 全体的な傾向 は図-8の $x$ 軸周りの渦度と同様, 当初は壁近傍で発達 し, フロント進入と供に徐々に水路内部にも発生, フロ ント到達前後で水路全体に 3 次元的に発達するという ものである.ただし $x$ 軸周りと異なり,$y$ 軸周りの渦の 巻き込みによる影響を受けにくいため, $x$ 軸周りの渦度 が 3 次元性を獲得していくタイミングと一歩遅れて, そ の渦度の影響を受けながら発達していくと考えられる。

\section{5. まとめ}

本論では, CIP 法と LES 乱流モデルを用いた 3 次元 密度流数值計算モデルを構築し, 同様の条件下で行われ 

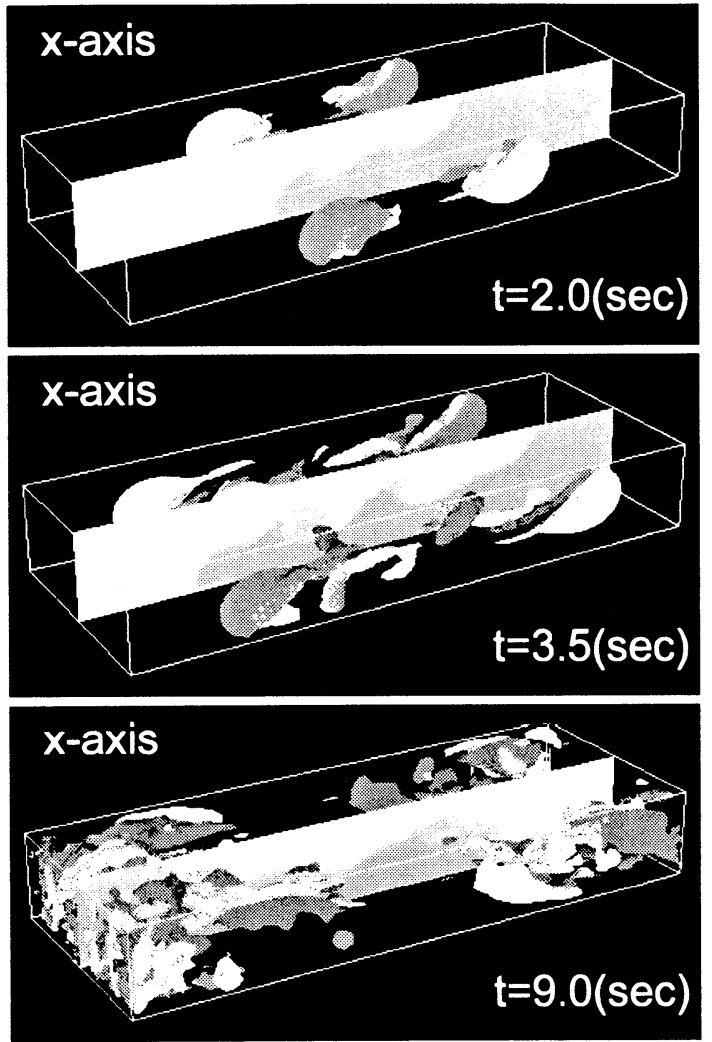

図-8 $x$ 軸方向周りの渦度の等値面 濃: $2.0(1 / \mathrm{sec})$, 淡: $-2.0(1 / \mathrm{sec})$

た実験や, 過去の類似の実験との比較を行うことでその 妥当性を検証した. その結果, 本モデルが高精度である ことが確認された。 また同モデルによる密度流の計算 結果をグラフィカルに検討することで, 密度フロントの 進入および内部セイシュの 3 次元性を確認した。

以上より本モデルが今後の密度流現象の理解のため の有効な手段となることが期待される。

\section{参考文献}

1) 池永均, 向山公人, 大島伸介, 山田正: 塩淡二成層を 形成する汽水湖沼の長期的な界面変動予測手法の開発, 土木学会論文集, No.628/II-48, pp.77-96, 1999.

2) 道奥康次, 辻本剛三, 宮本仁志: 半閉鎖水域におけ る風成密度流の水質交換特性, 水工学論文集, 第 39 巻, pp.805-810, 1995.

3) 池永均, 山田 正, 内島邦秀, 向山公人, 平野道夫, 井 出康朗: 網走湖における吹送流の発生と成層界面の挙 動に関する研究, 水工学論文集, 第 41 巻, pp.481-488, 1997.

4) 細田 尚, 西澤賢太郎, 福住 晃, 大久保賢治, 村本嘉雄: 交換密度流に生じる内部波に関寸る数值解析的研究, 水 工学論文集, 第 40 巻, pp.525-530, 1996.

5) Yabe, T and Aoki, T. : A universal solver for hyperbolic equations by cubic-polynomial interpolation I. One-dimensional solver, Comp. Phys. Comm., Vol.66, pp.219-232, 1991.

6) 赤堀良介, 清水康行, 中山 卓: 鉛直方向に密度境界面 を持つ流体の混合に関する数值計算, 水工学論文集, 第 43 巻, pp.521-526, 1999.
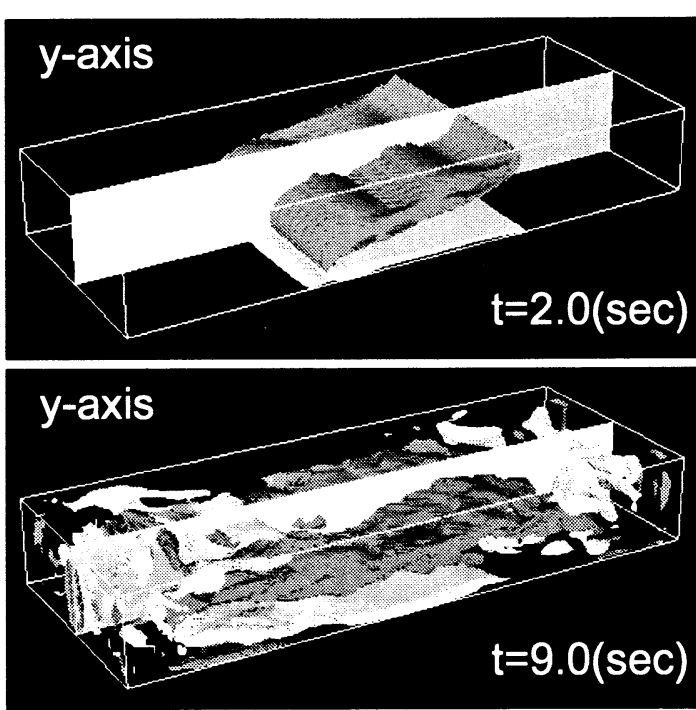

図-9 $y$ 軸方向周りの渦度の等值面

濃: $3.0(1 / \mathrm{sec})$, 淡: $-3.0(1 / \mathrm{sec})$
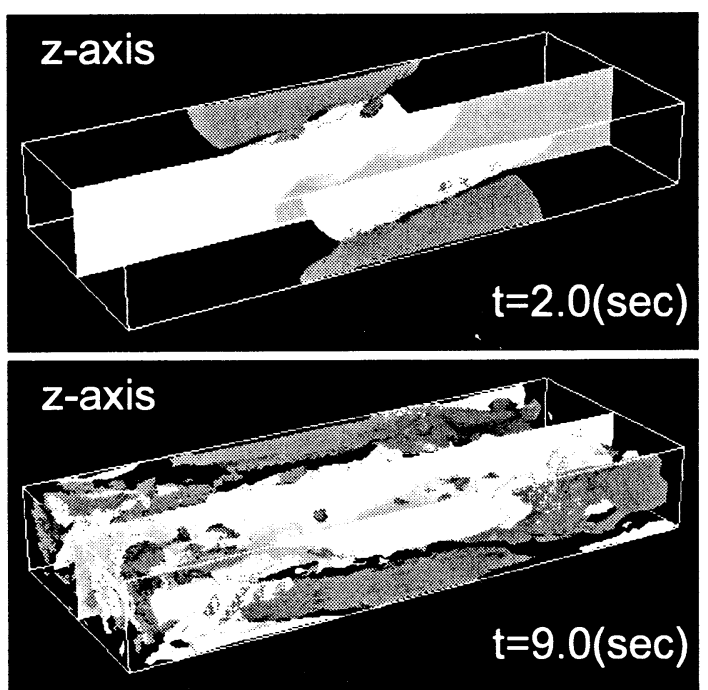

図-10 $z$ 軸方向周りの渦度の等値面

濃: $2.0(1 / \mathrm{sec})$, 淡: $-2.0(1 / \mathrm{sec})$

7) 数值流体力学編集委員会 編: 乱流解析, 東京大学出 版会, pp.67-118, 1995 .

8) 大宮司久明, 三宅 裕, 吉澤 徵 編: 乱流の数值流 体力学, 東京大学出版会, pp.412-422, 1998.

9) 河村 洋, 土方邦夫 編: 熱と流れのシミュレーショ ン, 丸善株式会社, pp.47-48, 1995.

10) Simpson, J. E. and Britter, R.E. : The dynamics of the head of a gravity current advancing over a horizontal surface, J. Fluid Mech., Vol.94, pp.477-495, 1979.

11) 大久保賢治: 湖における吹送流と密度流の発生・流 動機構に関する研究, 京都大学学位論文, 1988 .

12) 平野道夫, 山田正, 井出康朗: 網走湖における流動 と成層界面の挙動に関する観測, 水工学論文集, 第 35 巻, pp.609-614, 1991.

(1999. 9. 30 受付) 